\title{
PENERAPAN MODEL PEMBELAJARAN PROJECT BASED LEARNING UNTUK MENINGKATKAN KETERAMPILAN MENULIS PUISI DI SEKOLAH DASAR
}

\author{
Lia Marlani ${ }^{1}$, Anggi Giri Prawiyogi ${ }^{1}$ \\ ${ }^{1}$ Universitas Buana Perjuangan, Karawang, Jawa Barat, Indonesia \\ anggy.prawiyogi@ubpkarawang.ac.id \\ Naskah diterima: 25 Januari, 2019, direvisi: 1 Februari, 2019, diterbitkan: 31 Maret, 2019
}

\begin{abstract}
The background of this research is the low writing ability of students especially on poetry writing ability. This research was conducted in grade V, SDIT Cendikia. Learning model applied is model of Project Based Learning. The research method used in this research is Classroom Action Research. The research consisted of three cycles each. The purpose of this research is to know the activity and result of student learning on poetry writing ability, after applied of Project Based Learning model. Research data obtained through observation and test. From the results of this research can be concluded that the implementation of the of Project Based Learning model can improve the ability of writing poetry in class $V$. The results showed that the ability to write poetry can be increased, can be seen from the results of student learning completeness on the initial test students who meet the KKM as much as 2 people, then the second is 6 people, and the third cycle is 9 people, and 14 people on the third cycle of the number of students as many as 15 people. Therefore, students learning outcomes on writing poetry ability at the end of each cycle I to III have improved considerably. Based on the invention, it is suggested that the teacher can apply the learning of Project Based Learning model to improve poetry writing ability, as well as on other language ability.
\end{abstract}

Keywords: Project Based Learning Model, poetry writing ability

\begin{abstract}
ABSTRAK
Latar belakang penelitian ini adalah rendahnya keterampilan menulis siswa terutama pada keterampilan menulis puisi. Penelitian ini dilakukan di kelas V SDIT Cendekia. Model Pembelajaran yang diterapkan adalah model Project Based Learning. Metode penelitian yang digunakan pada penelitian ini adalah Penelitian Tindakan Kelas yang terdiri dari tiga siklus, di mana setiap siklus terdiri dari dua pertemuan. Tujuan penelitian ini adalah untuk mengetahui aktivitas dan hasil belajar siswa pada keterampilan menulis puisi, setelah dierapkan model Project Based Learning. Data penelitian diperoleh melalui observasi dan tes. Dari hasil penelitian ini dapat disimpulkan bahwa penerapan model Project Based Learning dapat meningkatkan keterampilan menulis puisi siswa kelas V. Hasil penelitian menunjukan bahwa kemampuan menulis puisi meningkat, dapat dilihat dari hasil ketuntasan belajar siswa pada tes awal siswa yang memenuhi KKM sebanyak 2 orang, siklus I sebanyak 6 orang, lalu pda siklus 9 orang, dan 14 orang pada siklus III dari jumlah siswa sebanyak 15 orang. Oleh karena itu, hasil belajar siswa pada ketrampilan menulis puisi pada akhir setiap pelajaran siklus I sampai siklus III mengalami peningkatan yang cukup baik. Berdasarkan temuan peneliti disarankan, agar guru dapat menerapkan model pembelajaran Project Based Learning untuk meningkatkan keterampilan menulis puisi, serta pada kemampuan berbahasa lainnya.
\end{abstract}

Kata kunci: Model Pembelajaran Project Based Learning, keterampilan menulis puisi. 


\section{PENDAHULUAN}

Bahasa Indonesia merupakan bahasa pengantar dalam suatu pembelajaran atau berlangsungnya pembelajaran sehingga Bahasa Indonesia memiliki posisi yang penting pada suatu proses pembelajaran. Bahasa Indonesia di setiap jenjang pendidikan formal merupakan suatu hal yang diharuskan karena dipergunakan untuk menyampaikan ilmu pengetahuan. Pembelajaran bahasa indonesia di Sekolah Dasar bertujuan untuk meningkatkan kemampuan siswa agar mampu berkomunikasi secara efektif, baik komunikasi lisan ataupun tulisan.

Salah satu keterampilan yang dipelajari oleh siswa di Sekolah Dasar adalah keterampilan menulis. Keterampilan menulis adalah salah satu keterampilan yang harus dikuasai oleh siswa di Sekolah Dasar. Saat siswa bisa menulis mereka belum tentu mempunyai keterampilan menulis. Keterampilan menulis diartikan sebagai kemampuan mengungkapkan ide atau gagasan melalui sebuah tulisan. Oleh karena itu menulis menjadi keterampilan yang sangat penting yang harus dimiliki oleh siswa. Melalui keterampilan menulis, setiap siswa bisa menghasilkan karya dalam kehidupannya. Sesuai dengan pernyataan di atas, diharapkan siswa mampu berkomunikasi secara lisan maupun tulisan serta melatih kreativitas dan bakat yang dimiliki.

Keterampilan menulis merupakan keterampilan berbahasa yang digunakan untuk berkomunikasi dengan orang lain. Tarigan $(1994,3)$ keterampilan menulis merupakan keterampilan berbahasa yang dipergunakan untuk berkomunikasi secara tidak langsung tidak secara tatap muka dengan yang lain. Menulis merupakan suatu kegiatan yang produktif dan efektif.

Selanjutnya Widjoko dan Endang $(2009,50)$ mengungkapkan bahwa puisi adalah ekspresi pengalaman batin (jiwa) penyair mengenai kehidupan manusia, alam dan sang pencipta, melalui media bahasa yang estetik secara padu dan utuh dalam bentuk teks.

Berdasarkan masalah yang ditemui di SDIT Cendekia saat pelajaran Bahasa Indonesia dalam pembelajaran menulis puisi, sebagian siswa mengalami kesulitan saat diberikan tugas untuk menulis puisi oleh guru. Setelah mengamati hasil menulis puisi, kesulitan yang dihadapi di antaranya kesulitan menemukan ide (inspirasi), mengembangkan kalimat menjadi bait, sulitnya mengembangkan ide ke dalam bahasa tulis bentuk puisi, terbatasnya perbendaharaan kata yang dimiliki oleh siswa, hingga kurangnya pemahaman siswa tentang unsur-unsur puisi. Namun ada juga siswa yang sudah mempunyai ide namun tidak dapat menuangkannya ke dalam bentuk puisi. Akibatnya, puisi yang dibuat siswa masih banyak yang menyerupai karangan narasi atau deskripsi.

Untuk menyelesaikan masalah yang ditemukan dalam proses belajar, guru harus pintar memilih pendekatan atau model pembelajaran yang tepat. Hal ini dimaksudkan agar tujuan pendidikan dapat tercapai sesuai dengan indikator kompetensi tiap pembelajaran. Salah satu model pembelajaran yang dapat diterapkan dalam mengatasi masalah yang timbul selama proses pembelajaran adalah model pembelajaran Project based learning. Dengan model Project based learning, siswa dapat berpikir untuk membuat suatu proyek atau karya pada pembelajaran dan terlibat langsung selama proses pembelajaran.

\section{HASIL DAN DISKUSI}

sub bab pembahasan hasil penelitian ini, akan dibahas mengenai data hasil perhitungan yang diperoleh selama proses penelitian tindakan kelas berlangsung. Berikut ini pembahasan data hasil selama penelitian. 
1. Aktivitas siswa

Aktivitas siswa merupakan salah satu yang dijadikan pengamatan oleh peneliti. Berdasarkan rumusan masalah, peneliti ingin mengetahui aktivitas siswa ketika menggunakan model pembelajaran Project Based Learning dalam pembelajaran Bahasa Indonesia dalam keterampilan menulis puisi. Dari hasil penelitian yang telah dilakukan dengan tiga siklus, aktivitas siswa pada saat menerapkan model Project Based Learning dilihat dari siklus I hingga siklus II Berdasarkan hasil pengamatan selama pembelajaran berlangsung di kelas V SDIT Cendekia, dengan menerapkan model pembelajaran Project Based Learning mengalami peningkatan.

Penerapan model pembelajaran Project Based Learning siswa setiap siklusnya mengalami peningkatan, persentase aktivitas siswa pada siklus I sebesar 59,35\% dengan kategori cukup walaupun sudah dalam keadaan cukup masih terdapat beberapa siswa yang masih kurang aktivitasnya. Hal ini disebabkan karena siswa yang belajar di kelas masih belum terbiasa dengan model pembelajaran yang digunakan pada saat KBM berlangsung. Kemudian setelah melakukan perbaikan, pada siklus II meningkat menjadi $71,1 \%$, dan pada siklus III mengalami peningkatan menjadi $80,87 \%$ dengan kategori baik. Aktivitas siswa pada siklus III mulai terlihat, siswa sudah mulai terbiasa dengan pembelajaran puisi yang berbasis proyek. Hal itu membuat aktivitas siswa pada siklus III meningkat dengan kategori sangat baik.

Berikut ini tabel analisis hasil observasi aktivitas belajar siswa pada silus I sampai dengan siklus III:

Tabel 1. Hasil observasi aktivitas siswa pada silus I sampai dengan siklus III

$\begin{array}{ccc}\text { Siklus } & \text { Presentase } & \text { Kategori } \\ \text { I } & 59,35 \% & \text { Cukup } \\ \text { II } & 71,1 \% & \text { Baik } \\ \text { III } & 80,87 \% & \text { Baik }\end{array}$

Berdasarkan tabel di atas, dapat disimpulkan bahwa aktivitas siswa selama penerapan model pembelajaran Project Based Learning selalu mengalami peningkatan. Penerapan model pembelajaran ini dapat meningkatkan aktivitas belajar siswa melalui pembelajaran yang menghasilkan sebuah proyek pada setiap pembelajaran. Hal tersebut mengindikasikan bahwa model pembelajaran Project Based Learning mempengaruhi peningkatan aktivitas belajar siswa.

2. Rekapitulasi Ketuntasan Belajar Siswa pada Menulis Puisi

Kemampuan siswa dalam keterampilan menulis puisi kelas V SD ini sebelum penerapan model pembelajaran Project Based Learning masih terhitung sangat rendah, terbukti dari nilai tes awal sebelum penerapan model pembelajaran Project Based Learning yang masih belum memenuhi KKM. Model pembelajaran Project Based Learning pada penelitian ini telah diatur untuk meningkatkan keterampilan menulis puisi siswa dan aktivitas belajar siswa.

Selama pelaksanaan pembelajaran dengan menerapakan model pembelajaran Project Based Learning siswa masih terlihat bingung apa yang harus dilakukan, sehingga peneliti sebagai guru memberikan petunjuk dan arahan selama pelaksanaan pembelajaran. Pada pertemuan selanjutnya 
siswa mulai mampu mengikuti kegiatan model pembelajaran Project Based Learning dengan cukup baik.

Berikut ini rekapitulasi hasil tes keterampilan menulis puisi siswa selama penelitian berlangsung:

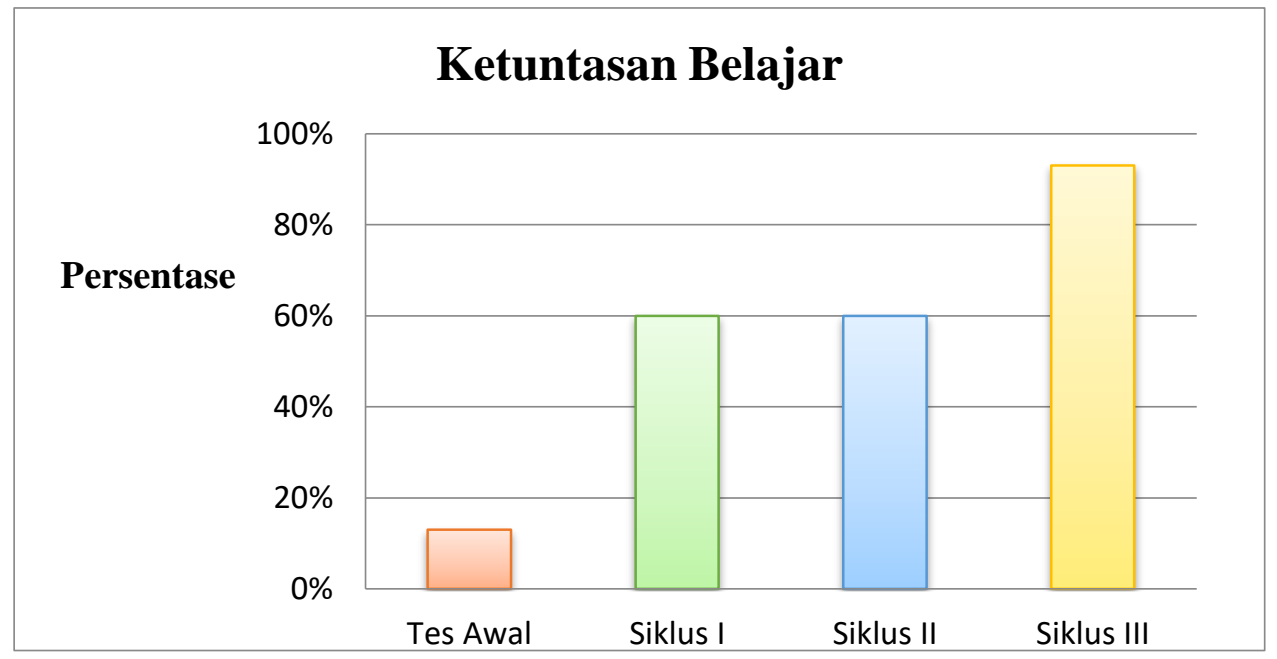

Diagram 1. Rekapitulasi ketuntasan belajar siswa dalam menerapkan model pembelajaran Project Based Learning

Berdasarkan data di atas dapat dilihat bahwa pada pembelajaran bahasa Indonesia dengan menerapkan model Project Based Learning dapat dikatakan berhasil karena pada setiap siklusnya terdapat peningkatan. Mulai dari pra siklus atau tes awal yang mendapat persentase sebesar 13\%, jumlah siswa yang mencapaai nilai KKM sebanyak 2 orang, pada siklus I 60\% dengan jumlah yang mencapai KKM sebanyak 6 orang, lalu pada siklus II mencapai $60 \%$ dengan siswa yang mencapai KKM sebanyak 9 orang. Kemudian pada siklus III mengalami peningkatan kembali yaitu 93\% dan siswa yang mencapai KKM sebanyak 14 orang dengan jumlah keseluruhan siswa sebanyak 15 orang. Hal ini membuktikan bahwa model pembelajaran Project Based Learning dapat meningakatkan keterampilan menulis puisi pada siswa Sekolah Dasar.

Peningkatan nilai siswa dapat terjadi karena perbaikan yang dilakukan oleh guru dengan cara merefleksi setiap tindakan dan mengulangi kembali setiap tindakan hingga target ketuntasan tercapai sesuai dengan tujuan dilakukannya penelitian ini yaitu untuk memeperbaiki permasalahan yang dialami siswa di kelas, dalam hal ini keterampilan menulis puisi. Hal ini sejalan dengan pendapat Natawijaya dalam Muslich $(2012,9)$ yang mengungkapkan bahwa Penelitian Tindakan Kelas adalah Penelitian Tindakan Kelas adalah pengkajian terhadap permasalahan praktis yang bersifat situasional dan kontekstual, yang diajukan untuk menentukan tindakan yang tepat dalam rangka pemecahan masalah yang dihadapi atau memperbaiki sesuatu.

\section{KESIMPULAN}

Penelitian ini menyimpulkan bahwa model pembelajaran Project Based Learning mampu meningkatkan aktivitas dan hasil belajar siswa pada pembelajaran bahasa Indonesia khususnya pada aspek keterampilan menulis puisi. Dan disarankan agar guru dapat 
menerapkan model pembelajaran ini untuk meningkatkan keterampilan dan kemampuan berbahasa lainnya.

\section{DAFTAR PUSTAKA}

Al-Tabany, T.I.B. (2014). Mendesain Mdel Pembelajaran Inovatif, Progresif, dan Kontekstual: Konsep, Landasan, dan Implementasinya Pada Kurikulum 2013 (Kurikulum Tematik Integratif/TK). Jakarta : Prenadamedia Group

Mulyasa. (2009). Praktik Penelitian Tindakan Kelas. Bandung : Remaja Rosadakarya Offset.

Muslich, M. (2012). Melaksanakan PTK Itu Mudah(Clasroom Action Research). Jakarta: BumiAksara

Tarigan, G.H. (1994). Menulis Sebagai Suatu Keterampilan Berbahasa. Bandung : Angkasa. Widjoko, \& Hidayat, E. (2009). Teori dan Sejarah Sastra Indonesia. Bandung : UPI Press

Wiriaatmadja, Rochiati. (2009). Metode Penelitian Tindakan Kelas. Bandung: PT. Remaja Rosdakarya. 